\title{
Glaxo bid 'reflects changing patterns of drug research'
}

London. Pharmaceutical research in Britain - including that in new fields such as cell and molecular biology - is heading for a shake-out following Monday's announcement by Glaxo, already one of the world's largest drug companies, that it is making a bid for its smaller rival, Wellcome plc.

Glaxo officials say that one of the main aims of the proposed take-over is to enable the new joint company, which it intends to call Glaxo Wellcome, to achieve the economies of scale needed to continue to pursue research leading to innovative new products in a highly competitive global environment.

If the deal goes ahead, it will also benefit biomedical research directly through the fact that Glaxo would acquire the 40 per cent of the shares

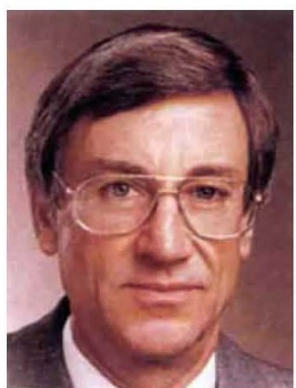

Sykes: job losses are 'inevitable'. in Wellcome that are currently owned by the Wellcome Trust, the body set up on the death of the company's founder, Henry Wellcome.

The trust is Britain's largest private source of research funding, operating on a scale comparable to the Howard Hughes Medical Institute in the United States - and with a research budget almost as large as that of the Medical Research Council. Last Sunday, it agreed in principle to accept Glaxo's offer, which values shares in Wellcome at 48 per cent higher than they were previously being quoted on the open market.

But the merger, which is now being considered by the board of Wellcome, would also lead to substantial job losses in both research and manufacturing. The activities of the two companies already overlap in a number of fields - for example, the treatment of cardiovascular disease and diseases of the central nervous system.

There is also concern in some quarters that the sheer size of the combined venture, which would become the largest private company in Britain, could lead it to play an excessively dominant role in determining future directions of pharmaceutical research.

Describing the reasons behind Glaxo's bid, which values Wellcome's share capital at $£ 8.9$ billion ( $\$ 14$ billion), Richard Sykes, the company's former research director who took over as chief executive two years ago, said that one powerful motivating factor had been a recognition of "a change in the way that drugs are going to be developed in the future".

A statement issued by the company ex- plained that while expertise based on traditional disciplines such as biochemistry and pharmacology continue to be applied in research, "increasing opportunities are being presented by newer but more costly technologies as a result of profound developments in cellular and molecular biology".

Sykes admitted that the planned 'rationalization' and streamlining of the research teams of the two companies, one of the main factors being used to generate support for the take-over among shareholders, will inevitably lead to job losses among researchers.

"Both our companies have excellent research pedigrees and an international reputation," he said. "In those area of research, such as cardiovascular disease, where each has people working, we will be looking to see which are the best programmes of the two, and than putting these together in the new company."

But, aware of the opposition that Glaxo's proposals are likely to generate from labour unions, Sykes also argued that increasing pressure on costs in the pharmaceutical industry world-wide meant that "there will be job losses, whether these two companies come together or not".

He pointed out that, even though Glaxo spends over $£ 1$ billion a year in research and development - more than any other British company - it still has only 3.9 per cent of the global drug market. "There has to be a change," Sykes said. "It cannot carry on that way, and we want to be in the lead in the process of consolidation."

In choosing to bid for a company with a complementary portfolio of pharmaceutical products, Glaxo has eschewed the strategy of some of its rivals - for example, the US company Merck Sharpe and Doehme who have opted for 'vertical integration' by merging with companies directly involved in patient care and disease management.

Sykes said that Glaxo had looked at this strategy in exploring other possible mergers, but had decided in the end "to stick to our basic objective of producing better medicines". He also said that the Wellcome Trust - which for legal reasons is declining to comment on Glaxo's bid - has indicated that it will "take a significant investment in the new group".

Indeed, the terms of the proposed acquisition, which would involve paying for Wellcome shares with a combination of cash and 'New Glaxo shares', will result in the trust holding 4.7 per cent of the joint company's share capital. But it will also leave the trust free to invest its endowment capital more flexibly than in the past.

David Dickson

\section{UK group to explore potential benefits of 'foresight' exercise}

London. As British government officials complete the final reports of the 15 panels engaged in its wide-ranging "technology foresight" exercise, preparations are already well advanced for a number of projects designed to analyse the results as soon as they are published and turn them into 'user friendly' form.

Last week, for example, the Centre for the Exploitation of Science and Technology (CEST), created in 1987 as a bridge between the research and industrial communities, announced the launch of a new fund to support the centre's research in fields ranging from transport to the life sciences.

Its first project will be to show companies how to gain a competitive advantage by applying to their corporate strategies the output of the foresight exercise launched in the wake of the 1993 white paper on science, and intended to generate a consensus on the most promising lines of new technological developments.

"British companies need to learn to hunt in packs if they are to exploit foresight's activities", says Bob Whelan, CEST's chief executive, adding that if Britain fails to make good use of the conclusions of the exercise, "we will have provided free-market intelligence to our competitors which they will have then take up and use in competition against us".

CEST hopes to raise $£ 5$ million towards its research activities over the next five years, part of which will come from subscriptions and donations from the centre's members, which include both large corporations and government departments.

The new fund is being seen in some quarters as a response to issues raised in an external review of the report activities of the centre, carried out at the end of 1993. This commended much of the centre's work, but said that many members felt that it needed to do more to justify their subscriptions (see Nature 368, 8; 1994).

- David Hunt, Britain's minister for science, announced on Tuesday that the government is to set up a committee to advise it on efforts to develop the public understanding of science. The new committee will be chaired by Sir Arnold Wolfendale, the Astronomer Royal, and will be made up of both practising scientists and science journalists.

Addressing a select committee of the House of Lords, Hunt also said that a project officer will be appointed to look into proposals for improving the conditions under which microbial culture collections are kept, and to recommend to Hunt's Office of Science and Technology the costs and benefits of the steps needed to achieve this goal. $\square$ 